\title{
EFFECT OF NANOAQUACITRATES ON PHYSIOLOGICAL PARAMETERS OF FODDER GALEGA INFECTED WITH PHYTOPLASMA
}

\author{
WPLYW NANOWODNYCH CYTRYNIANÓW NA PARAMETRY \\ FIZJOLOGICZNE GATUNKU GALEGA ZAKAŻONEGO FITOPLAZMA
}

\begin{abstract}
The laboratory experiments have been found that soaking seeds Galega orientalis L. (Fodder galega) in nanoaquacitrates solutions of Mn $\left(10\right.$ and $\left.20 \mathrm{mg} / \mathrm{dm}^{3}\right), \mathrm{Mo}\left(4 \mathrm{mg} / \mathrm{dm}^{3}\right)$ and $\mathrm{Mg}\left(2 \mathrm{and} 4 \mathrm{mg} / \mathrm{dm}^{3}\right)$, has been lead to germination energy rise, while Mn $\left(10\right.$ and $\left.20 \mathrm{mg} / \mathrm{dm}^{3}\right)$ and Mo $\left(4 \mathrm{mg} / \mathrm{dm}^{3}\right)$ concentrations has been influenced germinating ability. At the same time, the soaking seeds in solution of nanoaquacitrates $\mathrm{Mn}\left(20 \mathrm{mg} / \mathrm{dm}^{3}\right) \mathrm{had}$ the biggest stimulatory effect on the accumulation 7 daily sprouts mass (on 18\%). It has been shown that soaking seeds in nanoparticles $\mathrm{Mn}$ and Mo solutions leads to the increase of catalase activities (especially under the influence of manganese) and peroxidase activities (under molybdenum influence). Applying the method of chlorophyll $a$ fluorescence in the field and greenhouse experiments with Galega orientalis L. plants, artificial infected with phytoplasma Acholeplasma laidlawii var. granulum st. 118 the following changes in the photosynthetic apparatus has been indicated: reduction in the length of the light-antenna, blocking transport of electrons in plastoquinone pool PSII with reducing the pool of electron acceptors. It has also been indicated that photochemical activity resistance of the photosynthetic apparatus decreases while its stability increases, as result of described above effects the concentration of chlorophyll $a$ and $b$ in plants leaves decreases. The above-mentioned negative effects have been deactivated through foliar treatment of infected Galega orientalis L. plants with nanoaquacitrates solution Mo $\left(4 \mathrm{mg} / \mathrm{dm}^{3}\right)$ that allow increasing of photochemical resistance of photosynthetic apparatus as well as chlorophyll content in leaves. The foliar treatment with $\mathrm{Mn}\left(20 \mathrm{mg} / \mathrm{dm}^{3}\right)$ solution of the infected plants, in compared with infected plants without treatment, resulted in more significant increase of $K_{i}$ value (which correlate to the ribulose-1,5-bisphosphate carboxylase/oxygenase activity), which is explaining anti-mycoplasma effect of this solution.
\end{abstract}

Keywords: Galega orientalis L., Acholeplasma laidlawii var. granulum st. 118, photosynthetic apparatus, nanoaquacitrates solutions, catalase, peroxidase, chlorophyll $a$., chlorophyll $b$, chlorophyll $a$ fluorescence induction

\footnotetext{
${ }^{1}$ Institute of Microbiology and Virology NASU, Acad. Zabolotny 154, 03143 Kyiv, Ukraine, email: ab_k@ukr.net, tira@bigmir.net

${ }^{2}$ National University of Life and Environmental Sciences of Ukraine, Heroyiv Oborony 15, Kyiv - 03041, Ukraine, email: vimaksin@i.ua, kaplunenkov@mail.ru

${ }^{3}$ University of Opole, ul. R. Dmowskiego 7-9, 45-365 Opole, Poland, phone +48 787321587

* Corresponding author: akalinichenko@uni.opole.pl
} 


\section{Introduction}

The nanoparticles technology is an efficient and modern instrument, widely exploited in different fields of agricultural production, allowing minimization of chemical load on the environment [1-3]. The nanoaquachelates, due to their unique properties, are been used as agents with high antiseptic properties, insecticides for the effective control of pests for different crops, fungicides and effective fertilizers [2]. Some of them are widely applied as universal transporters and agents that are able to neutralize reactive oxygen compounds, including superoxide anion radical, hydroxyl radical, hydrogen peroxide. Nanoaquachelates may also be a cofactors of enzymes, participating in redox reactions [2, 3]. It should also be noted, that nanoparticles compared with salts of nutrients have a more prolonged effect. In agriculture much importance is given to development of different nanobiosensors and nanobases, which help to reduce natural resources use, with application such intellectual technologies for precise farming as satellite positioning, geographic information systems and remote sensing devices use that can remotely detect pathogens of crops, deficiency or excess of moisture, the level of nutrients in the soil and its pollution [2].

Moreover, an additional advantage of using nanoparticles is their environmental safety and economic feasibility [1-3]. It is known, that size of metal nanoparticles is less than $100 \mathrm{~nm}$. Complex compounds, which consist of complex agents (one or more metal nanoparticles) that have an electric charge and ligands (molecules of water) are called aquachelates. Through chelating of metal nanoparticles with water molecules, particles easily penetrate through the cell membrane, which creates conditions for their high activity. The peculiarity of the nanoaquachelates of nutrient metals is their high capacity to activate of physiological and biochemical processes in living organisms, due to their corpuscular, wave, quantum and other properties. In addition, they have high diffusion mobility, which also activates metabolism [1].

Numerous studies are emphasizing the role of such antioxidant enzymes as catalase and peroxidase, the substrate of which is hydrogen peroxide that are markers reflecting the plant stress resistance ability [4-6]. Several researches had indicated correlation between activation of such enzymes, as alpha-amylase, beta-amylase, catalase, peroxidase and protease, involved in stimulating the processes of seed germination, plant growth and development [7]. It has been shown that activity of catalase, lipid peroxidation and chlorophyll concentrations were more sensitive to copper and zinc, than the growth processes [8].

Azooz et al. had investigated stimulating effect of optimal concentrations of copper, in particular $2 \mathrm{mmol}$, on biosynthesis of proline free amino acid and activity of antioxidant enzymes such as catalase, peroxidase and superoxidedismutase, ascorbateperoxidase that can serve as important components of the antioxidant protective mechanism against of phytotoxicity [9]. The impact of different light conditions on the activity of catalase and peroxidase in extracts of 8-days pea sprouts have been investigated, and the differences in enzyme activity between etiolated and green plants are marked [10]. It has been indicated that salt stress affects the increase of activity and the number of antioxidant enzymes in soybean tissue: catalase, ascorbateperoxidase, polyphenoloxidase, peroxidase, and higherproline, while zinc treatment reduced the effect of salt stress by increasing the integrity of roots cells membranes [11]. The negative correlation between the frequency of respiration and catalase activity in young leaves of barley plants has been indicated [12]. 
The increase of catalase activity (more than twice) as well as oligotrophic bacteria in the rhizosphere (by 94\% compared to control) have been found after soaking seeds of chickpeas in a colloidal solution of molybdenum nanoparticles in a wide range of concentrations, that has great potential for agricultural use [3]. At the same time, application of nanoaquachelates is remained actual for preventing or stoppage the spread of diseases caused by phytopathogenic microorganisms $[1,2]$.

The phytopathogenic phytoplasmas damage crops and impose risk significant crop loss in case of mass lesion, which lead to significant crop loss. This pathogen has been included to the register of the most dangerous pathogens with high harmfulness [13, 14]. It is discovered, that pathogenic mycoplasma Acholeplasma laidlawii var. granulum st. 118, which causes pale-green dwarfism is the most damaging for photosynthetic apparatus of wheat [15]. At the same time, the state and activity of photosynthetic apparatus is one of the main conditions for forming of high productivity crops. The efficiency of plants photosynthetic apparatus functioning could be measured with modern non-invasive method of chlorophyll $a$ fluorescence induction [16-22].

Therefore, investigation regulatory mechanisms that are the bases for its status and activity is the actuality for explore ways for optimization of production process. This remains actual for investigation of host-pathogen interactions. At the same time, the animal industry needs plant biomass of high quality, with high nutritional value, with balanced composition of proteins, fats, vitamins and minerals as well as other biologically active substances. The forage with such composition allows obtaining the high-quality meat and dairy products $[23,24]$.

One of such valuable forage crops that meets above mentioned requirements is Fodder galega (Galega orientalis L.), whose advantage is high rate of vegetative growth and enhanced content protein - $149-183 \mathrm{~g} / \mathrm{kg}$, wet mass - $302-328 \mathrm{~g} / \mathrm{kg}$, dry mass $10.27-14.23 \mathrm{Mg} / 10^{4} \mathrm{~m}^{2}-54.6 \%$ as well as the fat, sugar, carotene and other biologically active substances and nutrition elements [24]. It have been found that during three mowing Galega orientalis plants provide about $10.98 \mathrm{Mg} / 10^{4} \mathrm{~m}^{2}$ of dry biomass yield and $\mathrm{N}$ $120 \mathrm{~kg} / 10^{4} \mathrm{~m}^{2}$ [25] or providing $40-70 \mathrm{Mg} / 10^{4} \mathrm{~m}^{2}$ green biomass witch abounds to $10.27-14.23 \mathrm{Mg} / 10^{4} \mathrm{~m}^{2}$ dry biomass in a year, without application of pesticides and $\mathrm{N}$-fertilizer [26]. Therefore, Galega orientalis L. have high productivity and a capacity to fix atmospheric nitrogen in range $200-453 \mathrm{~kg} / 10^{4} \mathrm{~m}^{2}$ [27]. However, pathogens of various origin are able to infected plants Galega orientalis L., especially in the first year of cultivation. In this case, the biomass yield and its quality are reduced [13]. The climate conditions and type of cultivation also affect development of diseases [27-29]. The investigations had demonstrated that the gray mould and plant wilting are developing better in pure sowing, than at mixed sowing with smooth bromegrass (Bromus inermis L.) [29].

Our work was aimed on investigation of influence of soaking seeds and foliage treatment solutions of nanoparticles of molybdenum, manganese and magnesium on germination energy, germinating ability, sprouts growth and activity of catalase and peroxidase, as well as photochemical activity and chlorophyll content in leaves of plants Galega orientalis L. in conditions of artificial lesion by pathogenic phytoplasma Acholeplasma laidlawii var. granulum st. 118. 


\section{Materials and methods}

The laboratory, greenhouse and field experiments have been performed with Galega orientalis L. plants. Twenty five seeds were taken for each if 3 -fold repetition in Petri dishes in vitro, than soaked in different solutions of nanoaquacitrates $\mathrm{Mo}, \mathrm{Mn}$ and $\mathrm{Mg}$, (in laboratory experiments).

The following scheme has been used for experiments: 1 - control (water); 2 - seed soaking in Mo $\left(8 \mathrm{mg} / \mathrm{dm}^{3}\right) ; 3-\operatorname{Mo}\left(4 \mathrm{mg} / \mathrm{dm}^{3}\right) ; 4-\mathrm{Mn}\left(20 \mathrm{mg} / \mathrm{dm}^{3}\right) ; 5-\mathrm{Mn}\left(10 \mathrm{mg} / \mathrm{dm}^{3}\right)$; $6-\operatorname{Mg}\left(4 \mathrm{mg} / \mathrm{dm}^{3}\right) ; 7-\mathrm{Mg}\left(2 \mathrm{mg} / \mathrm{dm}^{3}\right)$.

Seeds germination energy and mass growth have been determined in 7-day sprouts of Fodder galega.

The physiological effect, $E_{p h y}$, has been calculated with formula:

$$
E_{p h y}=\frac{\left(M_{x}-M_{o}\right)}{M_{o}} \cdot 100
$$

where: $M_{o}$ - means mass of plant, grown in control; $M_{x}$ - means plant mass or length after soaking (in experiment). The quantities obtained in this experiment, were analyzed considering its size and the effect, that could be either stimulatory - at $E_{p h y}>0$ or inhibitory (phytotoxic) - at $E_{\text {phy }}<0$. That effect is considered significant at $\geq 20 \%$.

After seeds soaking 3-4 days in solutions nanoaquacitrates solutions, the measurement of antioxidant enzymes activity (catalase (EC 1.11.1.6) and peroxidase (EC 1.11.1.7)) has been performed in sprouts tissues in each individual of wet mass sample. In order to measure their fermentative activity, 100-200 mg wet mass sample has been homogenized in mortar with distillate, placed in calibrated flask and filled with water up to $25 \mu^{3}$ level.

The homogenate has been filtered and $5 \mu \mathrm{m}^{3}$ of it has been incubated for 6 hs with $5 \mu \mathrm{m}^{3}$ of $0.3 \%$ hydrogen peroxide solution, then $5 \mu \mathrm{m}^{3}$ of $1.1 \mathrm{~mol}$ sulfuric acid has been added for the reaction termination. The undegraded peroxide titrated with $0.01 \mathrm{~mol}$ potassium permanganate $\mathrm{KMnO}_{4}$ to slightly pink color that stays for about $60 \mathrm{~s}$ : $5 \mathrm{H}_{2} \mathrm{O}_{2}+2 \mathrm{KMnO}_{4}+3 \mathrm{H}_{2} \mathrm{SO}_{4} \rightarrow \mathrm{K}_{2} \mathrm{SO}_{4}+2 \mathrm{MnSO}_{4}+8 \mathrm{H}_{2} \mathrm{O}+5 \mathrm{O}_{2}$.

For enzymes inactivation, the control (blank) sample of homogenate has priory been warmed on a boiling water bath for $300 \mathrm{~s}$, then filled with $5 \mu \mathrm{m}^{3} 0.3 \%$ solution of hydrogen peroxide, and $1.1 \mathrm{~mol}$ sulfuric acid for termination of the incubation. The obtained solution had been titrated with potassium permanganate. The catalase activity, $A$, has been calculated with the formula:

$$
A=\frac{(K-O) \cdot 0.85 \cdot E}{T}
$$

where: $K$ - amount of $\mathrm{KMnO}_{4}$, has been used for titration in control (blank) sample $\left[\mu \mathrm{m}^{3}\right]$; $O$ - amount of $\mathrm{KMnO}_{4}$, has been used for titration in experiment $\left[\mu \mathrm{m}^{3}\right] ; 0.85$ - amount of $\mathrm{H}_{2} \mathrm{O}_{2} \mu \mathrm{m}^{3}$, corresponding to $1 \mu \mathrm{m}^{3} 1.1$ mol $\mathrm{KMnO}_{4} ; T$ - incubation time $(600 \mathrm{~s})$; $E$ - dilution. The catalase activity (EC 1.11.1.6) that has been reflected in the amount of $\mathrm{O}_{2}$, generated in result of enzyme activity during $60 \mathrm{~s}$ from $1 \mathrm{~g}$ wet mass $\left(\mu \mathrm{m}^{3} \mathrm{O}_{2} \cdot \mathrm{g} \cdot 60 \mathrm{~s}^{-1}\right)$. Nonspecific peroxidases (EC 1.11.1.7) activity has been investigated by Boyarkin's method based on the measurement of benzidine (1,1'-biphenyl-4,4'-diamine) oxidation speed to the blue color resultant. The color change rate of work solution has been determined by optical density rate at FEC $(\lambda=670 \mathrm{~nm})$. Peroxidase activity has been measured in relative units per wet mass $-\mathrm{g}^{-1} \cdot \mathrm{s}^{-1}$. 
The plants of Galega orientalis L. have been grown in greenhouse and field conditions on research areas (area $70 \mathrm{~m}^{2}$ ) of Zabolotny Institute of Microbiology and Virology. Inoculation with pathogenic strain has been carried out in the phase of 2 true leaves. The pathogen of pale green dwarf wheat - A. laidlawii var. granulum st. 118 (UKM VM-34) have been received from the Ukrainian collection of microorganisms of Zabolotny Institute of Microbiology and Virology NANU (Ukraine). Artificial inoculation with agent has been performed using Clément's method (subepidermic injection). In field experiments 9-daily Galega orientalis L. plants have been foliage treated with citrates of nanoaquachelates Mo, $\mathrm{Mn}$ and $\mathrm{Mg}$ with initial active nanoparticles concentrations of $800 \mathrm{mg} / \mathrm{dm}^{3}, 2 \mathrm{~g} / \mathrm{dm}^{3}$ and $4 \mathrm{~g} / \mathrm{dm}^{3}$ respectively. Nanoaquachelates of metals $\mathrm{Mo}, \mathrm{Mn}$ and $\mathrm{Mg}$ have been received by erosive-explosive method. The "LLC Nanomaterials and Nanotechnologies" procreator. Field and greenhouse experiments have been performed applying the same scheme: 3 days past artificial infection with phytoplasma, the plants have been foliage treated with Mo, $\mathrm{Mn}, \mathrm{Mg}$ nanoaquachelates solutions in different concentrations and under different conditions: Mo $\left(8 \mathrm{mg} / \mathrm{dm}^{3}\right), \mathrm{Mn}\left(20 \mathrm{mg} / \mathrm{dm}^{3}\right) \mathrm{Mg}\left(4 \mathrm{mg} / \mathrm{dm}^{3}\right)$ - in greenhouses and Mo $\left(4 \mathrm{mg} / \mathrm{dm}^{3}\right), M n\left(10 \mathrm{mg} / \mathrm{dm}^{3}\right), M g\left(2 \mathrm{mg} / \mathrm{dm}^{3}\right)$ - in field experiments.

The general scheme of experiments: 1 - control (uninfected plant); 2 - the foliage treatment of uninfected Fodder galega plants with solutions containing 4 and $8 \mathrm{mg} \mathrm{Mo} / \mathrm{dm}^{3} ; 3$ - the foliage treatment of uninfected Fodder galega plants with solutions which contain 10 and $20 \mathrm{mg} \mathrm{Mn} / \mathrm{dm}^{3} ; 4$ - the foliage treatment of uninfected Fodder galega plants with solutions containing 2 and $4 \mathrm{mg} \mathrm{Mg} / \mathrm{dm}^{3} ; 5$ - plants, artificially infected with A. laidlawii var. granulum st. 118 (without foliage treatment); 6 - plants, artificially infected with A. laidlawii var. granulum st. 118 with foliage treatment 4 and $8 \mathrm{mg} \mathrm{Mo} / \mathrm{dm}^{3}$; 7 - plants, artificially infected with $A$. laidlawii var. granulum st. 118 with foliage treatment 10 and $20 \mathrm{mg} \mathrm{Mn} / \mathrm{dm}^{3} ; 8$ - the plants, artificially infected by A. laidlawii var. granulum st. 118 with foliage treatment 2 and $4 \mathrm{mg} \mathrm{Mg} / \mathrm{dm}^{3}$.

The pigments composition of Galega orientalis L. leaves in field experiments were measured through 2 weeks after treatment with nanoparticles with extraction method in DMSO with followed by spectrometry [30].

Photochemical activity of photosynthetic apparatus of leaves has been measured with biophysical method of chlorophyll $a$ fluorescence induction using portable device «Floratest», which has been designed in Glushkov's Institute of Cybernetics NASU (Ukraine). The device is equipped with a LCD display (128 - 64 pixels) and remote optoelectronic radiation sensor of $470 \pm 15 \mathrm{~nm}$ irradiation wavelength, area irradiation of light spot is not less than $15 \mathrm{~mm}^{2}$ and light within it not less than $2.4 \mathrm{~W} / \mathrm{m}^{2}$. The spectral range of fluorescence measurements is within 670-800 nm. The «Floratest» software, provided with the device performs the measured data import via computer USB-port and displays the data in tabular or graphical form [15]. The chlorophyll a fluorescence induction method have been performed with 10 and 240-second's measurements series on leaves of the upper tiers of Fodder galega on the 7th and 9th days after infection and on 9th and 11th days after treatment with nanoparticles respectively. The chlorophyll $a$ fluorescence measurements have been quintuple repeated. The measurements have been performed on the leaves of upper tier. Before the CFI measurement, leaves (kept in darkness for $1200 \mathrm{~s}$, covered with thick paper).

From numerical data array, received by measurements for 10 and 240 seconds, the arithmetic mean values have been calculated and Kautsky's curves have been built [16-22]. The critical parameters of curves have been analyzed: minimal fluorescence, $F_{o}$ 
[RU]; maximal fluorescence, $F_{p}=F_{m}$ [RU] or fluorescence level with high intensity of flash applied (assuming, that all PSII antenna sites have been closed at the moment); the variable fluorescence has been calculated as $F_{v}=F_{m}-F_{o}$; the ratio of variable fluorescence to maximal fluorescence $\left(F_{v} / F_{m}\right)$ - is a measure of the maximum quantum efficiency of PSII (when all PSII centers open); $K_{p l}-Q_{B}$ - amount of non-renewable complexes that do not participate in the linear electron transport, has been calculated as $K_{p l}=\left(F_{p l}-F_{o}\right) /\left(F_{m}-F_{o}\right)$; $1 / 2 t$ - is half the time needed to reach the variable fluorescence; $K_{i}$ - value is correlated with the intensity of ribulose-1,5-bisphosphate carboxylase/oxygenase activity (Rubisco), calculated as $K_{i}=\left(F_{m}-F_{t}\right) / F_{m}[15-22,31,32]$.

The stability of the photosynthetic apparatus of Fodder galega plants under artificial infection and foliage nanoaquacitrates treatment has been determined as the relative difference in $F_{o}$ and calculated as $\left(F_{o}\right.$ (7-day) $/ F_{o}$ (9-day)), while the sustainability of photochemical activity has been calculated as the quantum yield difference at photochemical energy conversion: $\left(F_{v}(7\right.$-day $) / F_{v}(9$-day $\left.)\right)$. These parameters have also been used as indicators to evaluate stressful temperatures influence on photochemical apparatus [33].

Statistical analysis have been performed with Statistica 8.0 and Excel applications use.

\section{Results}

It has been found in our investigations that nanoaquacitrate solutions influence on Fodder galega germination energy efficiency appears in following order: $10 \mathrm{mg} \mathrm{Mn} / \mathrm{dm}^{3}$ > $2 \mathrm{mg} \mathrm{Mg} / \mathrm{dm}^{3}>4 \mathrm{mg} \mathrm{Mg} / \mathrm{dm}^{3}>20 \mathrm{mg} \mathrm{Mn} / \mathrm{dm}^{3}>4 \mathrm{mg} \mathrm{Mo} / \mathrm{dm}^{3}$. The germinating ability has been stimulated by soaking seeds in solutions of $4 \mathrm{mg} \mathrm{Mo} / \mathrm{dm}^{3}, 10 \mathrm{mg} \mathrm{Mn} / \mathrm{dm}^{3}$ concentrations in the greatest degree, while $20 \mathrm{mg} \mathrm{Mn} / \mathrm{dm}^{3}$ - less (Table 1). The essential growth-stimulation effect on wet mass accumulation of 7-days sprouts has been induced with soaking seeds Galega orientalis $\mathrm{L}$. in $20 \mathrm{mg} \mathrm{Mn} / \mathrm{dm}^{3}$ nanoaquacitrate solution. At the same time, weak gain in wet mass of sprouts have been observed at seed soaking with 2 and $4 \mathrm{mg} \mathrm{Mg} / \mathrm{dm}^{3}$ solutions (Table 1).

Table 1

Soaking seeds Galega orientalis L. with different nanoaquacitrates concentrations influence on germination energy, germinating ability and accumulation of wet mass

\begin{tabular}{|c|c|c|c|c|c|c|}
\hline \multirow{2}{*}{$\begin{array}{c}\text { Sample of seeds } \\
\text { soaking }\end{array}$} & \multicolumn{3}{|c|}{ Germination energy [\%] to control } & \multirow{2}{*}{$\begin{array}{c}\text { Germinating } \\
\text { ability }\end{array}$} & \multirow{2}{*}{\multicolumn{2}{|c|}{$\boldsymbol{E}_{\text {phym }}{ }^{*}$}} \\
\hline & 1 day & 2 day & 3 day & & & \\
\hline Mo $\left(8 \mathrm{mg} / \mathrm{dm}^{3}\right)$ & 88 & 91 & 91 & 93 & 1 & normal \\
\hline Mo $\left(4 \mathrm{mg} / \mathrm{dm}^{3}\right)$ & 104 & 117 & 117 & 124 & 3 & normal \\
\hline $\mathrm{Mn}\left(20 \mathrm{mg} / \mathrm{dm}^{3}\right)$ & 113 & 117 & 121 & 106 & 18 & significant stimulation \\
\hline $\mathrm{Mn}\left(10 \mathrm{mg} / \mathrm{dm}^{3}\right)$ & 133 & 143 & 147 & 115 & 7 & tendency to stimulation \\
\hline $\mathrm{Mg}\left(4 \mathrm{mg} / \mathrm{dm}^{3}\right)$ & 117 & 121 & 121 & 97 & 10 & weak stimulation \\
\hline $\operatorname{Mg}\left(2 \mathrm{mg} / \mathrm{dm}^{3}\right)$ & 121 & 126 & 126 & 78 & 14 & weak stimulation \\
\hline
\end{tabular}

* - the physiological effect calculated from accumulation of wet mass

The change of activity of enzymes - catalase (EC 1.11.1.6) and peroxidase (EC 1.11.1.7) has been found in tissues of etiolated Fodder galega sprouts as a results seeds soaking in nanoaquacitrates solutions. The change of catalase activity has been observed in tissues three - four day sprouts Galega orientalis L. in following order: $20 \mathrm{mg} \mathrm{Mn} / \mathrm{dm}^{3}$ > $4 \mathrm{mg} \mathrm{Mo} / \mathrm{dm}^{3}>10 \mathrm{mg} \mathrm{Mn} / \mathrm{dm}^{3}>8 \mathrm{mg} \mathrm{Mo} / \mathrm{dm}^{3}>2 \mathrm{mg} \mathrm{Mg} / \mathrm{dm}^{3}>4 \mathrm{mg} \mathrm{Mg} / \mathrm{dm}^{3}$ (Fig.1a). 
The peroxidase activity in tissues of sprouts has increased only in result of seed soaking in $10 \mathrm{mg} \mathrm{Mn} / \mathrm{dm}^{3}$ and $4 \mathrm{mg} \mathrm{Mo} / \mathrm{dm}^{3}$ nanoaquacitrates solutions concentrations, while remaining on peroxidase activity the control level at concentrations of $4 \mathrm{mg} \mathrm{Mg} / \mathrm{dm}^{3}$ and $20 \mathrm{mg} \mathrm{Mn} / \mathrm{dm}^{3}$, and decreasing at concentrations $2 \mathrm{mg} \mathrm{Mg} / \mathrm{dm}^{3}$ and $4 \mathrm{mg} \mathrm{Mo} / \mathrm{dm}^{3}$ (see. Fig. 1b).
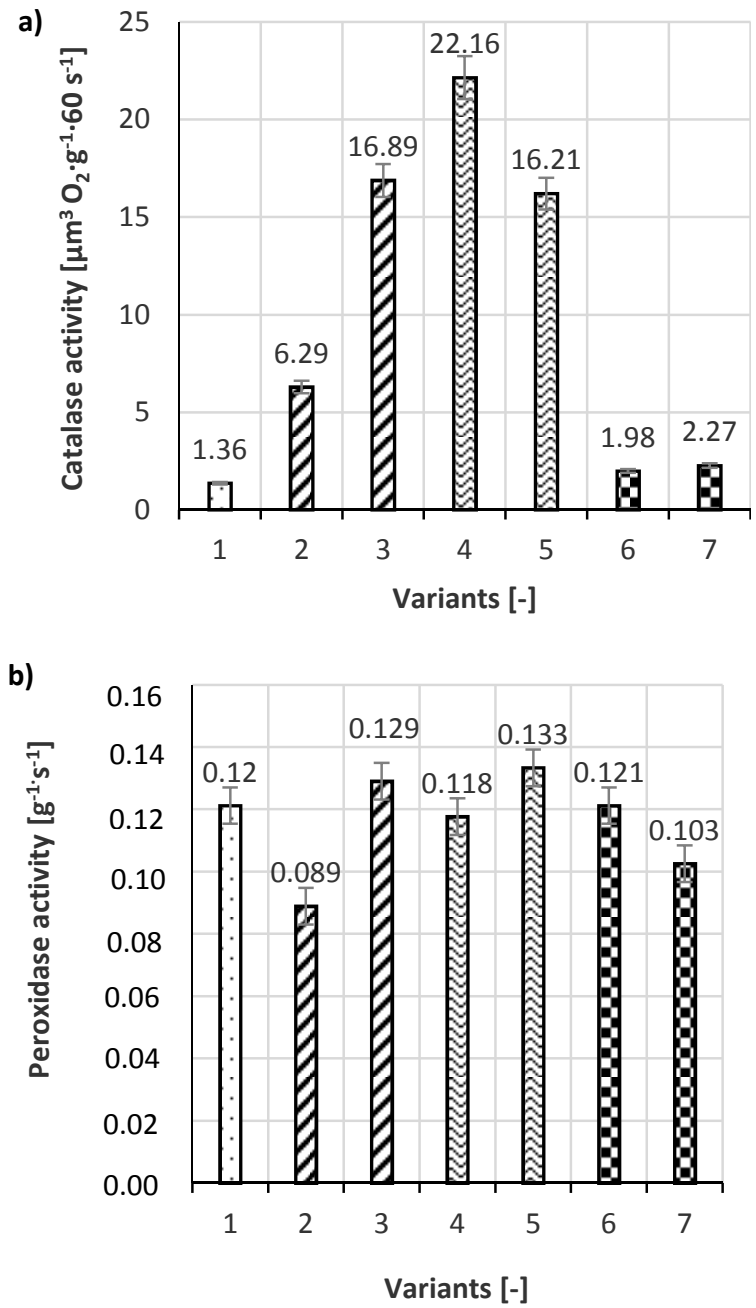

Fig. 1. The influence of soaking seeds in $\mathrm{Mo}, \mathrm{Mn}, \mathrm{Mg}$ nanoaquacitrate solutions on: a) catalase and b) peroxidase activities in tissue of 3-4-day Fodder galega sprouts (Variants: 1 - Control; 2 - Mo $\left(8 \mathrm{mg} / \mathrm{dm}^{3}\right) ; 3-\mathrm{Mo}\left(4 \mathrm{mg} / \mathrm{dm}^{3}\right) ; 4-\mathrm{Mn}\left(20 \mathrm{mg} / \mathrm{dm}^{3}\right) ; 5-\mathrm{Mn}\left(10 \mathrm{mg} / \mathrm{dm}^{3}\right) ; 6-\mathrm{Mg}\left(4 \mathrm{mg} / \mathrm{dm}^{3}\right)$; $\left.7-\mathrm{Mg}\left(2 \mathrm{mg} / \mathrm{dm}^{3}\right)\right)$

Interestingly, that seeds soaking in Mn solution $\left(20 \mathrm{mg} / \mathrm{dm}^{3}\right)$ has stimulated germination energy increase by $21 \%$ and germinating ability increase by $6 \%$ (see Table 1 ), while the highest catalase activity in tissues - 22,16 $\mathrm{mm}^{3} \mathrm{O}_{2} \cdot \mathrm{g}^{-1} \cdot 60 \mathrm{~s}^{-1}$ against 
$1,36 \mu \mathrm{m}^{3} \mathrm{O}_{2} \cdot \mathrm{g}^{-1} \cdot 60 \mathrm{~s}^{-1}$ in control has been observed of 3-4-day and highest intensity of wet mass accumulation after 7 days, and finally highest simulative effect for wet mass accumulation $(18 \%)$ has been indicated in case of seeds soaking Mn solution $\left(20 \mathrm{mg} / \mathrm{dm}^{3}\right)$.

17 and $47 \%$ increase of germination energy has been observed on the third day of soaking seeds in Mo $\left(4 \mathrm{mg} / \mathrm{dm}^{3}\right)$ and $\mathrm{Mn}\left(10 \mathrm{mg} / \mathrm{dm}^{3}\right)$ solutions correspondingly, while correspondingly 24 and $15 \%$ germinating ability increase have been sown and on the fourth day. Besides that, the high level of catalase activity $-16,89 \mu \mathrm{m}^{3} \mathrm{O}_{2} \cdot \mathrm{g}^{-1} \cdot 60 \mathrm{~s}^{-1}$ and $16.21 \mu^{3} \mathrm{O}_{2} \cdot \mathrm{g}^{-1} \cdot 60 \mathrm{~s}^{-1}$ has been indicated in tissues of sprouts as well as the tendency for peroxidase activity increase (by 7 and $7.4 \%$ respectively), although no significant simulative effect on of wet mass growth has been observed at seeds soaking in mentioned above concentrations.

The germination energy has increased by 21 and $26 \%$ in result seed soaking in 2 and $4 \mathrm{mg} \mathrm{Mg} / \mathrm{dm}^{3}$ solutions respectively while accumulation of wet mass has increased slightly. Catalase activity in sprouts tissues increased (by a factor of 1.5 and 1.7 respectively) in result of seeds soaking in solutions of mentioned above aquananoparticles concentrations, which is not as significant as it was in result other solutions application.

Certainly, the stimulating effect of divalent cations could be foreseen since divalent cations, magnesium and manganese in particular, influence the phosphorylation reaction, activating enzymatic activity.

Critical parameters of fluorescence have been found from Kautsky's curves, basing on CFI method measurement data (Fig. 2).

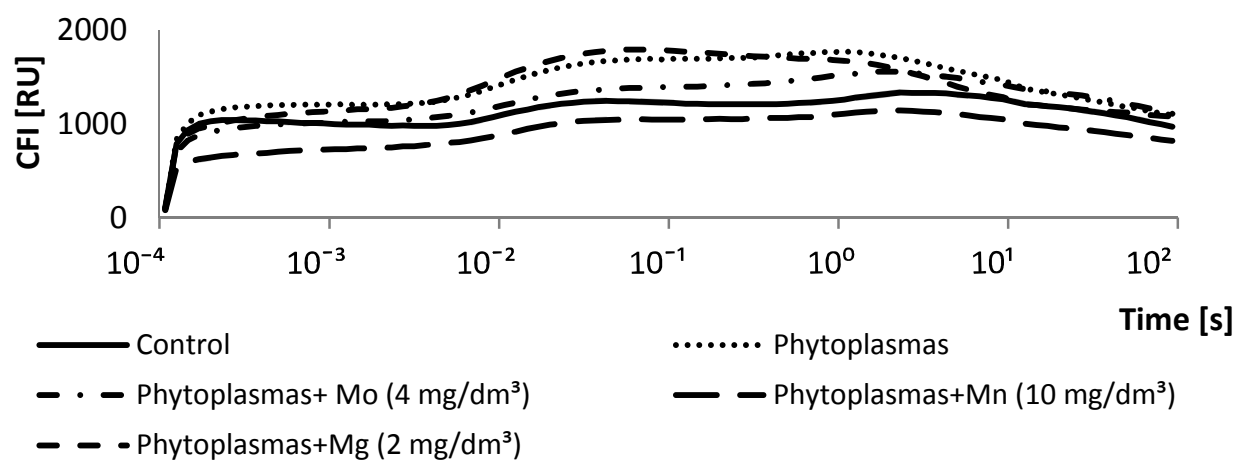

Fig. 2. Kautsky's curve for Fodder galega leaves (after been kept in darkness for 1200 s), RU - relative units

The CFI method investigations of artificially infected Fodder galega leaves photochemical activity have shown an increase of minimal fluorescence and decrease of the maximum quantum efficiency of PSII (or efficiency of photochemistry PSII, calculated as $\left.\left(F_{v} / F_{m}\right)\right)$ and reduction of the time to reach half of the variable fluorescence in photosintetic apparatus of leaves (Fig. 3 a, b, d) after 9-days after infection. The minimal fluorescence $\left(F_{o}\right)$ increase has been observed in the leaves of phytoplasma infected plants (Fig. 3a) and detected on the initial stage of illumination, when all the antenna centers are open and max of excitation energy reach of the antenna complexes. $F_{o}$ increase indicates reduction of 
active chlorophyll, connected to pigment-protein centers and participates in assimilation of quanta energy of light [16-22].

Mo $\left(4 \mathrm{mg} / \mathrm{dm}^{3}\right)$ and $\mathrm{Mn}\left(10 \mathrm{mg} / \mathrm{dm}^{3}\right)$ solutions foliage treatment has resulted in reduction of minimal fluorescence in infected plants leaves which indicates stabilization of light-harvesting complex (or antenna complex). Generally, the photochemistry`s quantum efficiency PSII $\left(F_{v} / F_{m}\right)$ has been reduced in the infected of Fodder galega leaves by ninth day, though foliage treatment with Mo $\left(4 \mathrm{mg} / \mathrm{dm}^{3}\right)$ solutions has been the most effective and $F_{v} / F_{m}$ value increased compared to control upward (Fig. 3b).

a)

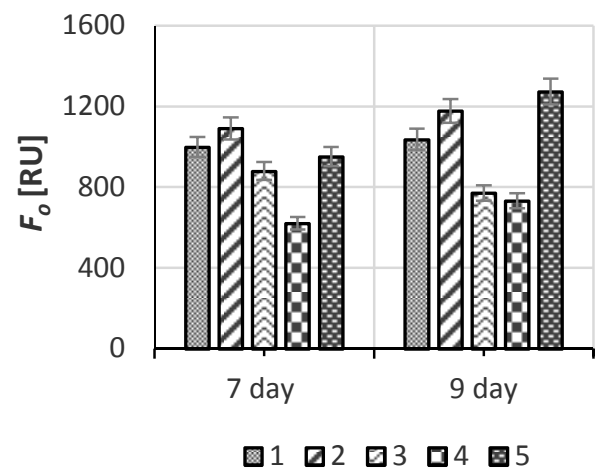

c)

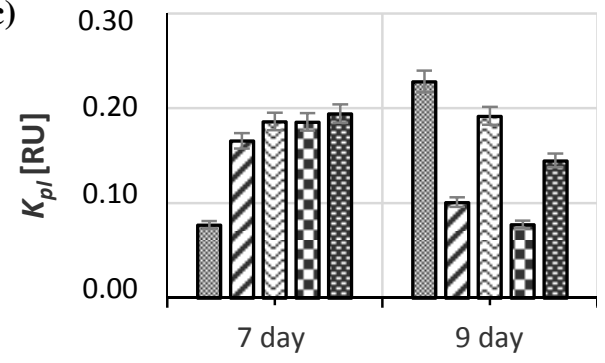

圆1 ロ2 日3 ロ4 田5 b)

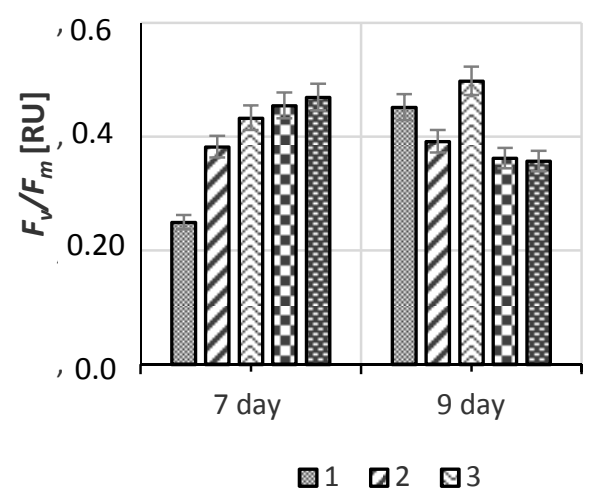

d)

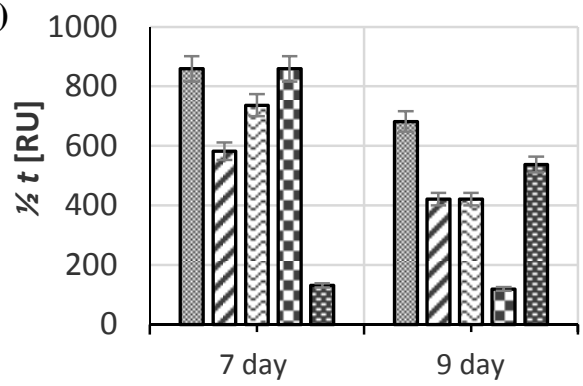

田1 ロ2 日3 ロ4 固5

Fig. 3. Changes of chlorophyll $a$ fluorescence parameters in the fast phase of fluorescence: a) $-F_{o}$, b) $F_{v} / F_{m}$, c) $K_{p l}$, d) $1 / 2 t$ in leaves Fodder galega artificially infected by A. laidlawii var. granulum st. 118 with following foliage treatment by nanoaquacitrate solutions in 7-9 days after infection (field conditions). (Variants: 1 - Control; 2 - Phytoplasma; 3 - Phytoplasma + Mo $\left(4 \mathrm{mg} / \mathrm{dm}^{3}\right) ; 4$ - Phytoplasma + Mn $\left(10 \mathrm{mg} / \mathrm{dm}^{3}\right) ; 5$ - Phytoplasma + Mg $\left.\left(2 \mathrm{mg} / \mathrm{dm}^{3}\right)\right)$

It has been detected that $K_{p l}$ value indicating the amount of non-renewable $Q_{B}$ - complexes and not participating in linear electron transmission in electron transport chain has increased on seventh day after infection (Fig. 3c). However, $K_{p l}$, decrease has been observed on the ninth day while this value decrease in result of at nanoaquacitrate foliage treatment compared to control. It has also been observed that the foliage treatment with nanoaquacitrate solutions of artificially infected Fodder galega leaves causes tendency 
to $K_{p l}$ further increase, which has very likely been regulatory (Fig. 3c). The time to reach half of the variable fluorescence $(1 / 2 t)$ in infected leaves of plants has reduced, which indicates a reduction of the pool of electron acceptors, but in 7 days after foliage treatment with nanoaquacitrates solutions of molybdenum $\left(4 \mathrm{mg} / \mathrm{dm}^{3}\right)$ and manganese $\left(10 \mathrm{mg} / \mathrm{dm}^{3}\right)$ this value has significantly increased (Fig. 3d). Consequently, on the 9 th day after foliage treatment with magnesium nanoaquacitrate $\left(2 \mathrm{mg} / \mathrm{dm}^{3}\right) 1 / 2 t$ - value has increased while after molybdenum treatment this value has remained at the level of infected leaves without treatment.

a)

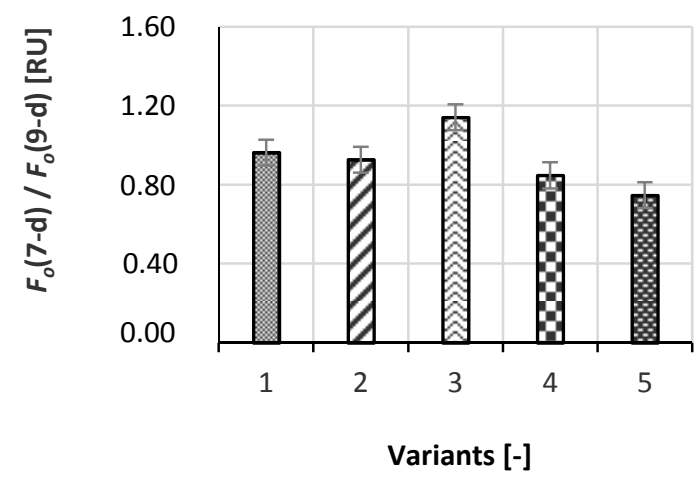

b)

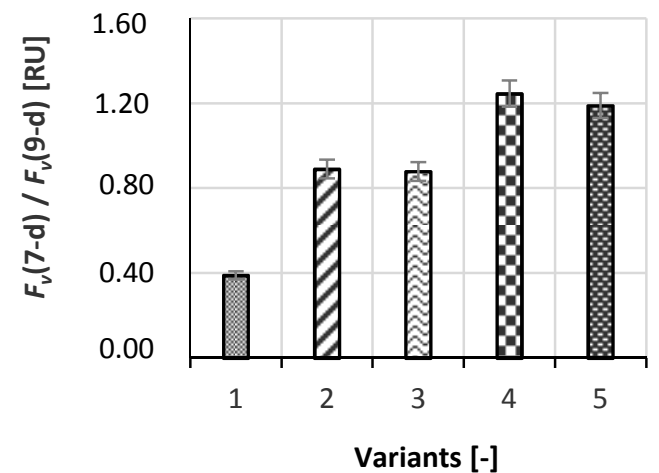

Fig. 4. a) Stability of light-harvesting complexes $-F_{o}$ (7-day) $/ F_{o}$ (9-day) and b) sustainability of photochemical activity $-F_{v}$ (7-day) $/ F_{v}$ (9-day) of upper tier leaves Fodder galega plants with artificial infection A. laidlawii var. granulum st. 118 and foliage treatment with nanoaquacitrate solutions (Variants: 1 - Control; 2 - Phytoplasma; 3 - Phytoplasma + Mo (4 mg/dm $\mathrm{dm}^{3}$ ); 4 - Phytoplasma + Mn (10 mg/dm $\left.{ }^{3}\right) ; 5$ - Phytoplasma + Mg $\left(2 \mathrm{mg} / \mathrm{dm}^{3}\right)$ (in field conditions))

In 7 to 9 days after Fodder galega leaves have been infected with phytoplasma of the tendency for the increase of light-harvesting complexes stability (Fig. 4a) has been indicated, which may identify suppression of new chlorophyll's molecules synthesis or their destruction. The light-harvesting complexes stability (LHC stability) increases after $\mathrm{Mn}\left(10 \mathrm{mg} / \mathrm{dm}^{3}\right)$ and $\mathrm{Mg}\left(2 \mathrm{mg} / \mathrm{dm}^{3}\right)$ solutions foliage treatment of infected plants, while 
after Mo $\left(4 \mathrm{mg} / \mathrm{dm}^{3}\right)$ treatment it has alternatively been reduced (Fig. $\left.4 \mathrm{a}\right)$. Such impact of nanoparticles could be associated with activation of wet mass accumulation; similar impact has been indicated for sprouts after soaking seeds in these solutions (Table 1), it also could be associated to inhibition of pathogens. Beside the impact on LHC stability, decrease of sustainability of photochemical activity in infected plants has been indicated during seventh to ninth day from the beginning of infection (Fig. 4b).

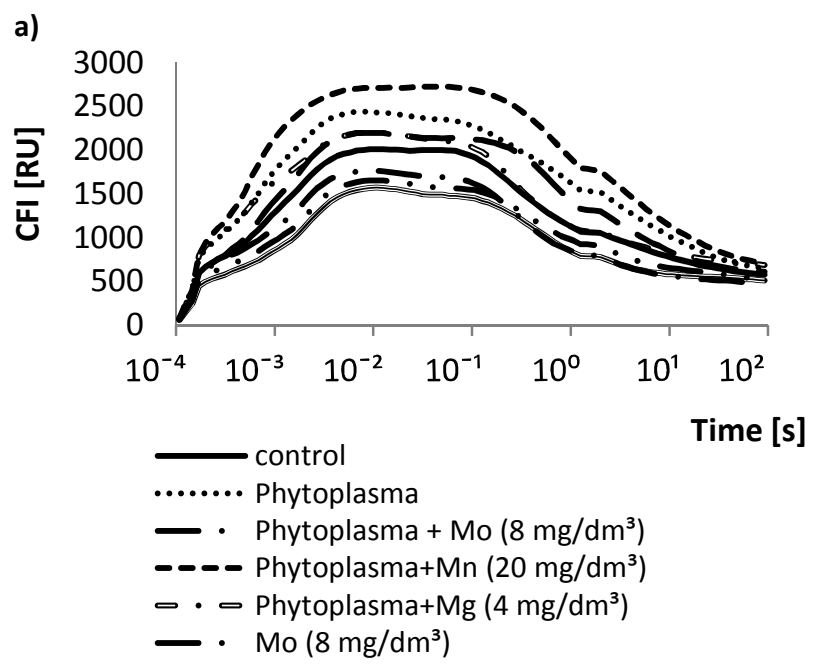

b)

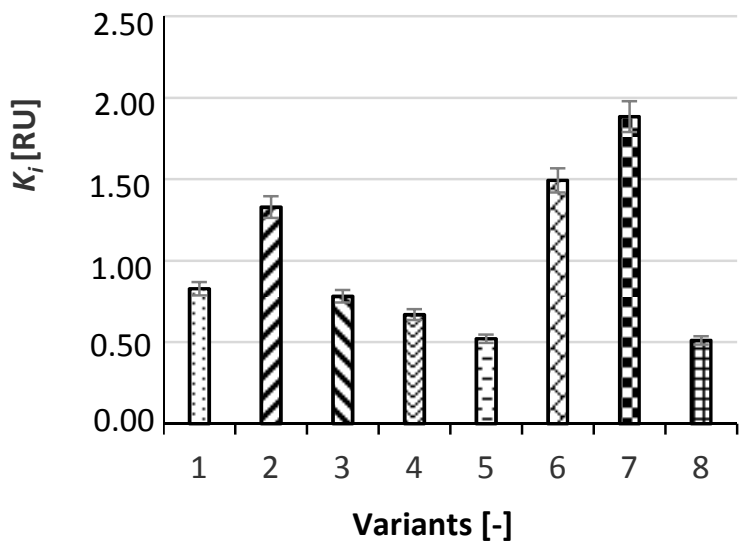

Fig. 5. a) Kautsky's curve and b) value of CFI parametr $K_{i}$ in slow phase of fluorescence for Fodder galega leaves after artificial infection with A. laidlawii var. granulum st. 118 and foliage treatment with nanoaquacitrates solutions (greenhouse culture) (the dark-adapted state of photosynthetic systems (1200 s) (Variants: 1 - Control; 2 - Phytoplasma; 3 - Mo $\left(8 \mathrm{mg} / \mathrm{dm}^{3}\right)$; 4 - Phytoplasma + Mo $\left(8 \mathrm{mg} / \mathrm{dm}^{3}\right) ; 5-\mathrm{Mn}\left(20 \mathrm{mg} / \mathrm{dm}^{3}\right) ; 6$ - Phytoplasma $+\mathrm{Mn}\left(20 \mathrm{mg} / \mathrm{dm}^{3}\right)$; 7 - Mg $\left(4 \mathrm{mg} / \mathrm{dm}^{3}\right) ; 8$ - Phytoplasma $\left.+\mathrm{Mg}\left(4 \mathrm{mg} / \mathrm{dm}^{3}\right)\right)$ 
Further treatment with nanoaquacitrates of manganese and magnesium has reduced this value, but molybdenum foliage treatment has created tendency to its growth. It is possible, that these changes would become more substantial over the period longer then the period of our experiment, at same time, considering all the data collected, including the quantum efficiency of photochemistry PSII increase, the most outstanding effect of all identified in present investigation has been observed after foliage treatment of nanoaquacitrate Mo $\left(4 \mathrm{mg} / \mathrm{dm}^{3}\right)$ infected Fodder galega.

Therefore, analyzing the "rapid" or "light" fluorescence phase, we can conclude that the most effective of all identified in present investigation is foliage treatment of infected Fodder galega plants with Mo $\left(4 \mathrm{mg} / \mathrm{dm}^{3}\right)$ nanoparticles concentration, since this concentration has contributed to the growth the quantum efficiency of photochemistry PSII $\left(F_{\downarrow} / F_{m}\right)$ in photosynthetic apparatus of infected plants leaves. It has also been found, that efficiency of mention above molybdenum nanoparticles concentration could be explained by sensitivity of pathogen to the mentioned nanoparticles concentration. This conclusion has been proved by laboratory investigations of various concentrations of molybdenum nanoparticles impact on growth and reproduction of phytoplasma.

The inhibition of pathogen growth has been observed under the influence of molybdenum nanoparticles at the concentration of $2 \mathrm{mg} / \mathrm{dm}^{3}$, while complete termination of growth has been indicated at concentration of $4 \mathrm{mg} / \mathrm{dm}^{3}$ mollicutes. However, the application of $\mathrm{Mn}$ nanoparticles in $10 \mathrm{mg} / \mathrm{dm}^{3}$ concentration, unlike molybdenum nanoparticles application, has not resulted in growth inhibition of Acholeplasma laidlawii var. granulum st. 118.

In our investigation, the growth inhibition of this mollicute have been observed only at $15 \mathrm{mg} \mathrm{Mn} / \mathrm{dm}^{3}$ nanoparticles concentration. It is necessary to underline, that $\mathrm{Mg}$ nanoparticles solution of 2 and $4 \mathrm{mg} / \mathrm{dm}^{3}$ concentrations had no effect on the growth of pathogenic strain Acholeplasma laidlawii var. granulum st.118.

Calculation of $K_{i}$ value (reflects the ribulose-1,5-bisphosphate carboxylase/oxygenase activity (Rubisco)) in fluorescence slow phase of affected plants leaves has demonstrated the increase of this value vs. the healthy plants. Most likely, it is happening due to the regulatory changes in the pathogen impact on Fodder galega plants metabolism (Fig. 5, var. 2). In addition, a significant increase of Rubisco activity has been detected in line with reduction of photochemical quantum efficiency as well as the reduction of light-harvesting complex antennas in the leaves of infected plants. It could be associated with oxygenase activity of this enzyme and photorespiration process that is competitive to photosynthesis processes. The significant increase of this value has been indicated after foliage treatment of, $\mathrm{Mg}$ nanoparticles $4 \mathrm{mg} / \mathrm{dm}^{3}$ solution and after $20 \mathrm{Mn} \mathrm{mg} / \mathrm{dm}^{3}$ solution treatment of infected plants (Fig. 5, var. 4, 8).

However, foliage treatment of Fodder galega plants with higher concentrations of nanoparticles has induced significant growth of $K_{i}$ value after $\mathrm{Mg}\left(4 \mathrm{mg} / \mathrm{dm}^{3}\right)$ foliage treatment, and downward tendency after Mo $\left(8 \mathrm{mg} / \mathrm{dm}^{3}\right)$ treatment and inhibition after Mn $\left(20 \mathrm{mg} / \mathrm{dm}^{3}\right.$ ) treatment (Fig. 5, var. 7, 3, 5). The highest increase of $K_{i}$ value (Fig. 5, var. 6) has been indicated in phytoplasma infected plants after Mn nanoparticles $\left(20 \mathrm{mg} / \mathrm{dm}^{3}\right)$ foliage treatment with while after $\mathrm{Mo}\left(8 \mathrm{mg} / \mathrm{dm}^{3}\right)$ and $\mathrm{Mg}\left(4 \mathrm{mg} / \mathrm{dm}^{3}\right)$ treatment this value has decreased compared to the control plants (Fig. 5, var. 4, 8). Such impact of nanoparticles on infected Fodder galega plants could be explained by following findings of our investigation: Mo of $8 \mathrm{mg} / \mathrm{dm}^{3}$ concentration inhibits the phytopathogens growth of, while demonstrating phytotoxic effect on the plants themselves; Mn of $20 \mathrm{mg} / \mathrm{dm}^{3}$ 
concentration - give stimulates the grows of wet mass and inhibits growth of phytopathogens; $\mathrm{Mg}$ of $4 \mathrm{mg} / \mathrm{dm}^{3}$ concentration positively affects the photosynthetic apparatus, without inhibiting the growth of pathogenic phytoplasma. The investigations of nanoaquacitrate foliage treatment have demonstrated that $\mathrm{Mg}\left(4 \mathrm{mg} / \mathrm{dm}^{3}\right)$ solution is the most effectively stimulator for the growth of chlorophyll $a$ content the plants after infection, while in case of the intact plants the higher concentration solutions could by places in the following order according to their efficiency level: $\mathrm{Mg}\left(4 \mathrm{mg} / \mathrm{dm}^{3}\right)>\mathrm{Mn}$ $\left(20 \mathrm{mg} / \mathrm{dm}^{3}\right)>$ Mo $\left(8 \mathrm{mg} / \mathrm{dm}^{3}\right)($ Table 2$)$.

Table 2

Photosynthetic pigments content in leaves of Fodder galega plants after artificial infection with phytoplasma and at foliage treatment of nanoaquacitrates solutions

\begin{tabular}{|c|c|c|c|c|}
\hline \multirow{2}{*}{ Treatment } & \multicolumn{4}{|c|}{ Photosynthetic pigments [mg/g w.m.] } \\
\hline & Chl. $a$ & Chl. $b$ & Chl. $(a+b)$ & Carotenoids \\
\hline \multicolumn{5}{|c|}{ Fodder galega (greenhouses) } \\
\hline Untreated Control & $1.59 \pm 0.07$ & $1.08 \pm 0.05$ & $2.67 \pm 0.13$ & $0.26 \pm 0.01$ \\
\hline phytoplasma* & $1.69 \pm 0.08$ & $0.97 \pm 0.04$ & $2.69 \pm 0.13$ & $0.11 \pm 0.01$ \\
\hline $\mathrm{Mg}\left(4 \mathrm{mg} / \mathrm{dm}^{3}\right)^{* *}$ & $1.84 \pm 0.09$ & $1.42 \pm 0.07$ & $3.27 \pm 0.16$ & $0.20 \pm 0.01$ \\
\hline $\operatorname{Mn}\left(20 \mathrm{mg} / \mathrm{dm}^{3}\right)^{* *}$ & $1.78 \pm 0.08$ & $1.10 \pm 0.05$ & $2.88 \pm 0.14$ & $0.45 \pm 0.02$ \\
\hline $\operatorname{Mo}\left(8 \mathrm{mg} / \mathrm{dm}^{3}\right)^{* *}$ & $1.68 \pm 0.08$ & $1.05 \pm 0.04$ & $2.74 \pm 0.14$ & $0.50 \pm 0.03$ \\
\hline phytoplasma $^{*}+\mathrm{Mg}\left(4 \mathrm{mg} / \mathrm{dm}^{3}\right)^{* *}$ & $1.81 \pm 0.09$ & $1.17 \pm 0.05$ & $2.99 \pm 0.14$ & $0.41 \pm 0.02$ \\
\hline phytoplasma $^{*}+\mathrm{Mn}\left(20 \mathrm{mg} / \mathrm{dm}^{3}\right)^{* *}$ & $1.30 \pm 0.06$ & $1.17 \pm 0.05$ & $2.47 \pm 0.12$ & $0.21 \pm 0.01$ \\
\hline phytoplasma + Mo $\left(8 \mathrm{mg} / \mathrm{dm}^{3}\right)^{* *}$ & $1.00 \pm 0.05$ & $1.08 \pm 0.05$ & $2.07 \pm 0.10$ & $0.11 \pm 0.01$ \\
\hline
\end{tabular}

w.m. - wet mass; ${ }^{*}$ - artificial infection with phytoplasma; ${ }^{* *}$ - leaves of Fodder galega plants, which foliage treated with nanoaquacitrates solutions

In intact plants, foliage treatment with nanoaquacitrate $\mathrm{Mo}\left(8 \mathrm{mg} / \mathrm{dm}^{3}\right)$ has the greatest influence on the content of carotenoids, that are protecting photosynthetic apparatus from photooxidation, whereas foliage treatment by nanoaquacitrate $\mathrm{Mg}\left(4 \mathrm{mg} / \mathrm{dm}^{3}\right)$ was the most effective for the content of carotenoids in leaves infected with Acholeplasma laidlawii var. granulum st. 118.

The chlorophyll content has been reduced after foliage treatment of infected plants with Mo $\left(8 \mathrm{mg} / \mathrm{dm}^{3}\right)$ solution, which indicates phytotoxic effect of the nanoparticles concentrations on plants.

\section{Conclusions}

The positive effects of foliage treatment with nanoaquacitrate solutions concentrations (Mo $\left(4 \mathrm{mg} / \mathrm{dm}^{3}\right)$ and $\mathrm{Mn}\left(20 \mathrm{mg} / \mathrm{dm}^{3}\right)$ on photochemical activity PSII of Fodder galega plants infected with Acholeplasma laidlawii var. granulum st. 118 has been shown in our investigation.

It has also been shown that molybdenum and manganese nanoparticles give positive influence on plants metabolism, particularly activating the germination energy by 17 and $21 \%$ correspondingly, as well as germinating ability by 24 and $6 \%$ accordingly.

The investigations has showed stimulating effect on accumulation of wet sprouts mass after seed soaking on Fodder galega in nanoaquacitrates solutions, particularly after treatment with manganese nanoparticles the wet mass growth has been increased by $18 \%$ and the level of catalase activity has significantly increases while peroxidase of activity has increased the most under the influence of molybdenum nanoparticles. 
Application of chlorophyll $a$ fluorescence method has revealed the following negative effects on photosynthetic apparatus of Galega orientalis L. leaves after artificial infection with phytoplasma Acholeplasma laidlawii var. granulum st. 118: degradation of pigmentprotein complexes and the reduction of light-harvesting complexes (or antenna complex of PSII), reduction of electron acceptors pool, reduction of quantum efficiency of photochemical activity PSII. These effects are reflecting the decrease of photosynthesis potential intensity. Additionally, it has been detected, that foliar treatment of infected plants Galega orientalis L. with nanoaquacitrates solutions Mo $\left(4 \mathrm{mg} / \mathrm{dm}^{3}\right)$ allowed to keep the quantum efficiency of photochemical activity PSII on level of control plants and above. This could be explained by the following effect, detected by investigation, that after foliar treatment of Mo nanoaquacitrates solutions the growth of Acholeplasma laidlawii var. granulum st. 118 has been inhibited, as well as enzymatic activity of plant tissues has been increased.

It has also been found, that increase of light-harvesting complexes stability indicator together with the decrease of photochemical activity sustainability indicator PSII of Galega orientalis L. leaves after 7- to 9-days after infection with phytoplasma, has been correlated with of chlorophyll concentration decrease in leaves.

It has been demonstrated, that foliage treatment with $20 \mathrm{mg} / \mathrm{dm}^{3} \mathrm{Mn}$ solution applied on infected Galega orientalis L. leads to significant increase the Ki value (Rubisco activity), which could been explained by antimycoplasma activity of this solution concentration, as well as by the impact of these particles on plant tissues enzymatic activity.

\section{References}

[1] Liu R, Lal R. Potentials of engineered nanoparticles as fertilizers for increasing agronomic productions. Sci Total Environ. 2015;514:131-139. DOI: 10.1016/j.scitotenv.2015.01.104.

[2] Duhan JS, Kumar R, Kumar N, Kaur P, Nehra K, Duhan S. Nanotechnology: The new perspective in precision agriculture. Biotechnol Rep (Amst). 2017;15:1-23. DOI: 10.1016/j.btre.2017.03.002.

[3] Taran NYu, Gonchar OM, Lopatko KG, Batsmanova LM, Patyka MV, Volkogon MV. The effect of colloidal solution of molybdenum nanoparticles on the microbial composition in rhizosphere of Cicer arietinum L. Nanoscale Res Lett. 2014;9(1):289. DOI: 10.1186/1556-276X-9-289.

[4] Mhamdi A, Queval G, Chaouch S, Vanderauwera S, Breusegem FV, Noctor G. Catalase function in plants: a focus on Arabidopsis mutants as stress-mimic models. J Experiment Bot. 2010;61(15):4197-4220. DOI: $10.1093 / \mathrm{jxb} / \mathrm{erq} 282$.

[5] Tanase C, Popa V. Peroxidase, superoxide-dismutase and catalase activity in corn plants developed under the influence of polyphenolic compounds and deuterium depleted water. A A I Cuza Univ, Sect IIa Genet Mol Biol. 2014;15(1):7-12. http://www.gbm.bio.uaic.ro/index.php/gbm/article/view/1098.

[6] Bakalova S, Nikolova A, Nedeva D. Isoenzyme profiles of peroxidase, catalase and superoxide dismutase as affected by dehydration stress and ABA during germination of wheat seeds. Bulg J Plant Physiol. 2004;30(1-2):64-77. https://journals4free.com/link.jsp?1=16815924.

[7] Choudhury S, Panda P, Sahoo L, Panda SK. Reactive oxygen species signaling in plants under abiotic stress. Plant Signal Behav. 2013;8(4):e23681. DOI: 10.4161/psb.23681.

[8] Soto P, Gaete H, Hidalgo ME Assessment of catalase activity, lipid peroxidation, chlorophyll-a, and growth rate in the freshwater green algae Pseudokirchneriella subcapitata exposed to copper and zinc. Lat Am $\mathrm{J}$ Aquat Res. 2011;39(2):280-285. DOI: 10.3856/vol39-issue2-fulltext-9.

[9] Azooz MM, Abou-Elhamd MF, Al-Fredan MA. Biphasic effect of copper on growth, proline, lipid peroxidation and antioxidant enzyme activities of wheat (Triticum aestivum cv. Hasaawi) at early growing stage. Aust J Crop Sci. 2012;6(4):688-694. https://www.researchgate.net/publication/231168321_Biphasic_ effect_of_copper_on_growth_proline_lipid_peroxidation_and_antioxidant_enzyme_activities_of_wheat_Tri ticum_aestivum_cv_Hasaawi_at_early_growing_stage.

[10] Luhova L, Lebeda A, Hedererova, Pec P. Activities of amino oxidase, peroxidase and catalase in seedlings of Pisum sativum L. under different light conditions. Plant Soil Environ. 2003;49(4):151-157. http://www.agriculturejournals.cz/publicFiles/52843.pdf. 
[11] Weisany W, Sohrabi Y, Heidari G, Siosemardeh A, Ghassemi-Golezani K. Changes in antioxidant enzymes activity and plant performance by salinity stress and zinc application in soybean (Glycine max L.). Plant Omics. 2012;5(2):60-67. http://www.pomics.com/sohrabi_5_2_2012_60_67.pdf.

[12] Stratu A, Olteanu Z, Peptanariu M, Zamfirache MM The intensity of respiration and the activity of some oxide - reductases in seeds of pastinaca sativa 1. treated with ultrasounds. An. ştiinţifice Univ "Al. I. Cuza" Iaşi Tomul LI, s. II a. Biol Vegetală., 2005;51:65-68. http://www.bio.uaic.ro/publicatii/ anale_vegetala/issue/2005/09-2005.pdf.

[13] Kyrylenko LV, Patyka VP Fungoid diseases of galega orientalis. Agr Microbiol. 2016;24:52-58. http://www.sg-microb.ho.ua/arh/pdf24/SM24_08EN.pdf.

[14] Second International Phytoplasmologist Working Group Meeting, Neustadt an der Weinstraße, Germany. 2011;12(15):303. www.bulletinofinsectology.org/.../insectology64-Supplement-2011.pdf

[15] Gulyaeva AB, Tokovenko IP, Korobkova KS, Patyka VP. Status and activity of the photosynthetic apparatus of wheat plants affected phytomycoplasmoses with phytohormones foliar treatment. J Sci World. 2015;10(26):52-56. http://scienceph.ru/d/413259/d/scienceandworldno10(26)octobervol.i_1.pdf.

[16] Henriques FS. Leaf chlorophyll fluorescence: background and fundamentals for plant biologists. Bot Rev. 2009;75:249-270. DOI: 10.10071/s12229-0099035y.

[17] Misra AN, Misra M, Singh R. Chlorophyll Fluorescence in Plant Biology. Biophysics. In: Misra AN, editor. 2012;7:171-192. http://www.intechopen.com/books/biophysics/chlorophyll-fluorescence-in-plant-biology.

[18] Papageorgiou GC, Govindjee G. Chlorophyll a Fluorescence: A Signature of Photosynthesis. In: Papageorgiou GC, Govindjee G, editors Netherlands: Springer. 2004. http://www.springer.com/ gp/book/9781402032172\#.

[19] Shavanova KE, Marchenko OA, Taran MV, Starodub MF. Express estimation of resistant the horse chestnut to the influence cameraria ohridella desch. \& dim. By using the method of the induction of chlorophyll fluorescence. Sci. Herald NULES. Ukr Ser: Biol Biotechnol Ecol. 2014;204:1-10. http://journals.nubip.edu.ua/index.php/Biologiya/article/view/4734.

[20] Stirbet A, Govindjee G. On the relation between the Kautsky effect (chlorophyll a fluorescence induction) and Photosystem II: Basics and applications of the OJIP fluorescence transient. J Photoch Photobiol. B. 2011;104(1-2):236-257. DOI: 10.1016/j.jphotobiol.2010.12.010.

[21] Stirbet A, Govindjee G. Chlorophyll a fluorescence induction: a personal perspective of the thermal phase, the J-I-P rise. Photosynth Res. 2012;113:15-61. DOI: 10.1007/s11120-012-9754-5.

[22] Żurek G, Rybka K, Pogrzeba M, Krzyżak J, Prokopiuk K. Chlorophyll a fluorescence in evaluation of the effect of heavy metal soil contamination on perennial grasses. PLoS One. 2014;9(3):e91475. DOI: 10.1371/journal.pone.0091475.

[23] Adamovics A, Dubrovskis V, Plume I. Galega for fodder and biogas production. 13th Int Conf of Forage Conservation. Nitra, Slovakia. 2008:170-171. https://www.cabdirect.org/cabdirect/abstract/20143176638.

[24] Peiretti PG, Gai F. Chemical composition, nutritive value, fatty acid and amino acid contents of Galega officinalis L. during its growth stage and in regrowth. Anim Feed Sci Tech. 2006;130(3-4):257-267. DOI: 10.1016/j.anifeedsci.2006.01.007.

[25] Slepetys J. Influence of cutting and management regimes on Fodder galega for forage and seed production. Agro Research. 2010;8(Sp.Iss.III):711-720. http://agronomy.emu.ee/vol08Spec3/p08s325.pdf.

[26] Slepetys J, Kadziuliene Z, Sarunaite L, Tilvikiene V, Kryzeviciene A. Biomass potential of plants grown for bioenergy production. Proc Intern Sci Conf: Renewable Energy and Energy Efficiency, Growing and Processing Technologies of Energy Crops. 2012;66-72. http://llufb.llu.lv/conference/ Renewable_energy_energy_efficiency/Latvia_Univ_Agriculture_REEE_conference_2012.pdf

[27] Patyka V, Buletsa N, Pasichnyk L, Zhitkevich N, Kalinichenko A, Gnatiuk T, et al. Specifics of pesticides effects on the phytopathogenic bacteria. Ecol Chem Eng $S$ 2016;23(2):311-331, DOI: 10.1515/eces-2016-0022

[28] Jeske M, Pańka D, Pala D, Czart A. The effect of different organic fertilization on fungi colonizing plant roots and seeds of fodder galega (Galega orientalis Lam.). 11th Conf Europ Found for Plant Pathology. Kraków: Publ House Krakow Agricult Univ; 2014; 191. http://www.efpp.net/Documents/Krakow/ Book\%20of\%20abstracts_11\%20EFPP\%20Conference_r.pdf.

[29] Cwalina-Ambroziak B, Koc J. Fungi colonising the aboveground parts of fodder galega (Galega orientalis Lam.) cultivated in pure sowing and mixed with smooth brome-grass (Bromus inermis Leyss.). Acta Agrobot. 2012;58(1):125-133. DOI: 10.5586/aa.2005.018.

[30] Hisox JD, Israelstam RJ. The method for the extraction of chlorofill from leaf tissue whithout maceration. Can J Bot. 1979;57(12):1332-1334. DOI: 10.1139/b79-163.

[31] Horton P, Ruban A. Molecular design of the photosystem II light-harvesting antenna: Photosynthesis and photoprotection. J Exp Bot. 2004;56(411):1-9. DOI: 10.1093/jxb/eri023. 
[32] Yamakawa H, van Stokkum IHM, Heber U, Itoh S. Mechanisms of drought-induced dissipation of excitation energy in sun- and shade-adapted drought-tolerant mosses studied by fluorescence yield change and global and target analysis of fluorescence decay kinetics. Photosynth Res. 2017;135(1-3):285-298. DOI: 10.1007/s11120-017-0465-9.

[33] Ribeiro RV, Santos MG, Pimentel C, Machado EC, Oliveira RF. Can the critical temperature for photochemical damage in common bean plants be changed after a drought event? Bragantia, Campinas. 2015;74(4):374-378. DOI: 10.1590/1678-4499.0141. 